\title{
Bioactive phytochemicals and antioxidant activity in fresh and dried lychee fractions ${ }^{1}$
}

\author{
Fitoquímicos bioativos e atividade antioxidante de frações de lichia frescas e secas
}

\author{
Estela de Rezende Queiroz ${ }^{2 *}$, Celeste Maria Patto de Abreu ${ }^{3}$, Kelly da Silva Oliveira ${ }^{3}$, Vinicius de Oliveira \\ $\operatorname{Ramos}^{3}$ e Rodrigo Martins Fráguas ${ }^{3}$
}

\begin{abstract}
Fruit of the lychee cv. Bengal are approximately 50\% peel and seeds, which are discarded. These byproducts have antioxidant compounds which are capable of blocking the harmful effects of free radicals in the body. Bioactive compounds (ascorbic acid, beta-carotene, lycopene and phenols) and antioxidant activity were evaluated in different extracts, both fresh and dried at $45{ }^{\circ} \mathrm{C}$, of the skin, pulp and seeds of the lychee, which were subjected to principal component analysis to clarify which of the compounds are responsible for this activity. Principal component analysis explained $82.90 \%$ of the variance of the antioxidant profile of the lychee. The peel displayed higher levels of phenols, ascorbic acid, beta-carotene and antioxidant activity, while the seeds stood out due to their levels of lycopene. With drying, there was a decrease in the levels of ascorbic acid and beta-carotene and in antioxidant activity, with an increase in the levels of phenols and lycopene. The antioxidant activity found in the peel and seeds of the lychee is high, and is mainly due to ascorbic acid and beta-carotene, as demonstrated by principal component analysis, allowing the use of these fractions as sources of natural antioxidants.
\end{abstract}

Key words: Lychee. Antioxidants. Principal component analysis.

RESUMO - Os frutos da lichieira cv. Bengal possuem aproximadamente 50\% de casca e semente, que são descartadas. Estes subprodutos apresentam compostos antioxidantes capazes de bloquear os efeitos danosos dos radicais livres, no organismo. Foram avaliados os compostos bioativos (ácido ascórbico, betacaroteno, licopeno e fenóis) e a atividade antioxidante, em diferentes extratos da casca, polpa e semente de lichia, in natura e secas a $45{ }^{\circ} \mathrm{C}$, os quais foram submetidos à análise de componentes principais, para elucidar quais compostos são responsáveis por esta atividade. A análise de componentes principais explicou $82,90 \%$ da variância do perfil antioxidante da lichia. A casca apresentou maiores teores de fenólicos, ácido ascórbico, betacaroteno e atividade antioxidante, enquanto a semente destacou-se pelos teores de licopeno. Com a secagem, houve decréscimo nos teores de ácido ascórbico e betacaroteno e na atividade antioxidante e aumento nos teores de fenólicos e licopeno. A atividade antioxidante encontrada na casca e semente de lichia é elevada e se deve, sobretudo, ao ácido ascórbico e ao betacaroteno, conforme demonstrado pela análise de componentes principais, o que possibilita o uso destas frações como fontes de antioxidantes naturais.

Palavras-chave: Lichia. Antioxidantes. Análise de componentes principais.

\footnotetext{
*Autor para correspondência

${ }^{1}$ Recebido para publicação em 22/11/2013; aprovado em 05/11/2014

Parte da Dissertação de Mestrado da primeira autora, apresentada ao Programa de Pós-Graduação em Agroquímica, Universidade Federal de Lavras ${ }^{2}$ Departamento de Química, Universidade Federal de Lavras/UFLA, Campus Universitário, Caixa postal 3017, Lavras-MG, Brasil, 37.200-000, estelaqueiroz@yahoo.com.br

${ }_{3}^{3}$ Departamento de Química, Universidade Federal de Lavras, Lavras- MG, Brasil, celeste@dqi.ufla.br, kellynhaso@hotmail.com, viniciusoramos@yahoo.com.br, rodrigofraguas1@hotmail.com
} 


\section{INTRODUCTION}

The lychee (Litchi chinensis Sonn.), a species of the Sapindaceae family suited to subtropical-climates, is of Chinese origin and is perfectly adapted to Brazilian climatic conditions. Fruit of the lychee cv. Bengal are about $50 \%$ peel and seed, which are discarded by both industry and consumers (KUMAR; KUMAR; SHARMA, 2012). Lychee production in the country has still not been determined (SMARSI et al., 2011), but is focused mainly in the southeast. In Brazil, industries that benefit from the lychee use the pulp in the preparation of ices and jams.

Recent work has been carried out, aiming to evaluate the nutritional potential of the by-products of lychee fruit, with initial results indicating that the peel and seed have high energy and nutritional potential (QUEIROZ; ABREU; OLIVEIRA, 2012). In addition, the peel and seed are rich in antioxidants such as ascorbic acid, phenolic compounds including gallic acid, flavonoids (procyanidin B4, procyanidin B2and epicatechin), and anthocyanins (cyaniding 3-rutinoside, cyanidin-3-glucoside, quercetin 3-rutinoside and quercetin 3-glucoside). Pharmacological studiesindicate that the by-products of the lycheehave various effects including anti-inflammatory, anti-hyperlipidemic, anti-hyperglycemic, hepatic and cardioprotective, as well as having high antioxidant activity (BHOOPAT et al., 2011; JIANG et al., 2013; XU et al., 2011).

A wide variety of in vivo and in vitro methodologies have been used to verify the antioxidant activity of isolated substances in food or drink. There is no one universal method by which this activity may be measured, since all methods have both advantages and disadvantages. More than one are therefore employed to determine this activity, such as the DPPH${ }^{\bullet}$ method (2.2-diphenyl-1-picrylhydrazyl) based on the capture of the $\mathrm{DPPH}^{-}$radical by antioxidants (SÁNCHEZ-MORENO, 2002), and the beta-carotene/ linoleic acid system, based on the oxidation of beta-carotene, induced by the products of the oxidative degradation of linoleic acid (DUARTE-ALMEIDA et al., 2006).

The fruit, recognized as a source of vitamins, minerals and fibre, is nutritionally important to our diet. In recent years, greater attention has been given to these foods, since evidence suggests that regular consumption of fruit is associated with reduced mortality and the morbidity of some chronic diseases (BHOOPAT et al., 2011; DEMBITSKY et al., 2011), as they contain in addition to nutrients, bioactive substances such as vitamins and secondary metabolites, which are capable of carrying out pharmacological activities.

Recent clinical and epidemiological studies show that phytochemicals are the major bioactive compounds of fruit, and prove that their consumption helps reduce the risk of cardiovascular diseases and cerebrovascular accidents, as well as reducing the incidence of certain types of cancers and oxidative stress (BHOOPAT et al., 2011; DEMBITSKY et al., 2011).

Given this advantage, the bioactive compounds and total antioxidant activity were evaluated in different extracts of the peel, pulp and seed of lychee fruit in natura, and in the peel and seed after being dried at $45^{\circ} \mathrm{C}$.

\section{MATERIAL AND METHODS}

Fruits of the lychee cv. Bengal from the 2010/2011 crop were harvested in a commercial orchard in Nepomuceno, in the Brazilian state of Minas Gerais (MG), $\left(21^{\circ} 20\right.$ ' $\mathrm{S}$, $45^{\circ} 23^{\prime} \mathrm{W}$ ), and transported to the Biochemistry Laboratory of the Department of Chemistry at the Federal University of Lavras. They were selected for uniform colouration of the peel (intense red), for their medium size and absence of defects. They were washed, sanitised with $200 \mu \mathrm{L} \mathrm{L}^{-1}$ sodium dichloroisocyanurate for 15 minutes, weighed, divided into two lots of 140 fruits and separated into peel, pulp and seed.

The peel, pulp and seed from the first batch were frozen in liquid nitrogen and stored in a freezer $\left(-20^{\circ} \mathrm{C}\right)$ until the analyses were carried out. The peel and seed from the second batch were dried in an oven at $45^{\circ} \mathrm{C}$ to constant weight, and stored in amber flasks; four days being needed to dry the peel and eight days to dry the seed.

The phenolic compounds were extracted with $50 \%$ methanol and quantified by the Folin-Denis method as described by Association of Official Analytical Chemistry (2012). The results were expressed in $\mathrm{mg}$ of phenolic compounds (equivalent to tannic acid) $100 \mathrm{~g}^{-1}$ of dry matter (DM).

The ascorbic acid was extracted in $0.5 \%$ oxalic acid with $0.1 \mathrm{~g}$ of added diatomaceous earth, quantified according to the methodology recommended by Strohecker and Henning (1967), and expressed in mg of ascorbic acid $100 \mathrm{~g}^{-1} \mathrm{DM}$.

The levels of beta-carotene and lycopene were determined according to Nagata and Yamashita (1992). To do this they were extracted with a solution of acetone and hexane (4:6) (v/v) in an ultrasonic bath at $4{ }^{\circ} \mathrm{C}$ for 5 minutes. After being filtered, the absorbances of the extracts were read in the $453 \mathrm{~nm}, 505 \mathrm{~nm}, 645 \mathrm{~nm}$ and $663 \mathrm{~nm}$ wavelengths.

To evaluate the antioxidant activity, four extracts were prepared using as the extracting solutions, distilled water (A), acetone (B), a 1:1 (v/v) $70 \%$ acetone and $50 \%$ ethanol solution (C) and 50\% methanol (D). The first three extracts (A, B and C) were obtained by agitating the samples in their respective solutions for 2 hours. The fourth extract (D) was obtained by extraction with $50 \%$ methanol in a reflux condenser at $80^{\circ} \mathrm{C}$; the methanol being removed by evaporation and the volume of the extract increased with distilled water. 
Antioxidant activity was determined by the $\mathrm{DPPH}^{\bullet}$ method, following Sánchez-Moreno (2002) with modifications. Three dilutions of the extracts A, $\mathrm{B}, \mathrm{C}$ and $\mathrm{D}$ were prepared. To $0.1 \mathrm{~mL}$ of each dilution was added $3.9 \mathrm{~mL}$ of $0.06 \mathrm{mM} \mathrm{DPPH}^{*}$ solution with the corresponding solvent being used as a blank. The absorbance at $515 \mathrm{~nm}$ was determined at the start and again after 30 minutes, the time for the absorbance to stabilise. The results were expressed in percentage of antioxidant activity.

Antioxidant activity by the carotene/linoleic acid system was determined according to Duarte-Almeida et al. (2006), with modifications. Three dilutions were prepared from each of the extracts $\mathrm{A}, \mathrm{B}, \mathrm{C}$ and $\mathrm{D}$, and $0.2 \mathrm{~mL}$ of each dilution were mixed with $2.5 \mathrm{~mL}$ of the carotene/ linoleic acid system solution. As control, $0.2 \mathrm{~mL}$ of a trolox in ethanol solution $\left(200 \mathrm{mg} \mathrm{L}^{-1}\right)$ was used with $2.5 \mathrm{~mL}$ of the system solution. The tubes were kept in a water bath at $40{ }^{\circ} \mathrm{C}$ for 2 hours. A reading $(\lambda=470 \mathrm{~nm})$ was taken 2 minutes after preparing the reaction mixture, and every 30 minutes for 2 hours. The results were expressed in percentage of antioxidant activity.

The experiment was carried out in a completely randomised design (CRD), consisting of 5 treatments (peel, pulp and seed in natura, and pulp and seed dried at $45^{\circ} \mathrm{C}$ ), using seven replications of 20 fruits. The results underwent variance analysis using the Sisvar statistical software (FERREIRA, 2011), and the treatment means were compared by Tukey test at $5 \%$ probability. Additionally, the Octavie 3.4.3 software (EATON, 2013) was used on the results to determine the principal components, and for this the data were centred around the mean and auto-scaled.

\section{RESULTS AND DISCUSION}

There was a significant difference $(>0.05)$ between the dried fractions and those in natura for all the parameters under test. The moisture content of the peel, pulp and seed

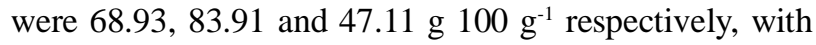
the highest water content being noted in the pulp.
Between the fractions in natura, the seed showed the lowest content for phenolic compounds $(11.45 \mathrm{mg}$ $\left.100 \mathrm{~g}^{-1} \mathrm{DM}\right)$, with no significant differences being found $(\mathrm{p}<0.05)$ between contents for the peel and pulp $(22.04$ and $21.20 \mathrm{mg} 100 \mathrm{~g}^{-1} \mathrm{DM}$ respectively), while the dry fractions showed levels for phenolic compounds which were significantly higher than those in natura $(\mathrm{p}>0.05)$ (Table 1), especially for the peel. Just as observed in grape and jabuticaba, these compounds are present in higher concentrations in the peel and seed (BOARI LIMA et al., 2008).

The higher content found for phenolic compounds in the dried peel and seed can be explained: it is believed that phenolic compounds in fruits are in the free form and/or associated with polysaccharides of the cell wall through hydrogen bonds between the hydroxyl groups of the phenolic compounds and the oxygen atoms of the polysaccharides (PINELO; ARNOUS; MEYER, 2006), and with drying there is a change in the nutritional value and in the physical and structural properties of fruits and vegetables. Even when this occurs at mild temperatures $\left(50{ }^{\circ} \mathrm{C}\right.$ for orange peel, $45^{\circ} \mathrm{C}$ for grape and jabuticaba peel), polymers in the cell wall are destroyed, particularly pectic substances, but in lesser amounts than at high temperatures (EBUN; SANTOSH, 2011; HARBOURNE et al., 2009; KIM et al., 2006). Removal of water from the lychee fractions may therefore have caused degradation of the cell wall, with the consequent hydrolysis releasing linked phenolic compounds and making them soluble, facilitating their extraction and resulting in an increase in the levels of the compounds seen in the dried peel and seed in relation to the fractions in natura.

Studies show that heating at temperatures of between 50 and $150{ }^{\circ} \mathrm{C}$ can convert insoluble phenolic compounds into soluble phenolics in grape peel and in broccoli, potatoes and onions, but it is unable to achieve this conversion in carrots and in cabbage cooked in the same way, or in rice hulls which have been dried at $100{ }^{\circ} \mathrm{C}$ (FALLER; FIALHO, 2009; KIM et al., 2006; LEE et al., 2003); this

Table 1 - Phenolic compounds (mg $\left.100 \mathrm{~g}^{-1} \mathrm{DM}\right)$, ascorbic acid (mg $\left.100 \mathrm{~g}^{-1} \mathrm{DM}\right)$, beta-carotene (mg $\left.100 \mathrm{~mL}^{-1}\right)$ and lycopene (mg $100 \mathrm{~mL}^{-1}$ ) for fractions of lychee fruit, Lavras, MG, 2011

\begin{tabular}{lcccc}
\hline Fraction & Phenolic compounds $^{(1)}$ & Ascorbic acid & Beta-carotene & Lycopene \\
\hline Peel in natura & $22.04 \mathrm{C}$ & $2.169 .52 \mathrm{~A}$ & $261.99 \mathrm{~A}$ & $-(2)$ \\
Seed in natura & $11.45 \mathrm{D}$ & $370.47 \mathrm{C}$ & $0.07 \mathrm{D}$ & $0.12 \mathrm{~B}$ \\
Pulp in natura & $21.20 \mathrm{C}$ & $453.19 \mathrm{~B}$ & $36.24 \mathrm{C}$ & - \\
Dried peel & $71.71 \mathrm{~A}$ & $225.98 \mathrm{D}$ & $195.09 \mathrm{~B}$ & - \\
Dried seed & $34.72 \mathrm{~B}$ & $75.67 \mathrm{E}$ & $2.70 \mathrm{D}$ & $4.33 \mathrm{~A}$ \\
\hline
\end{tabular}

Means followed by the same letter in a column do not differ by Tukey test at $5 \%$ probability; ${ }^{(1)}$ Expressed in equivalents of tannic acid; ${ }^{(2)}$ Not detected 
indicates that the phenolic compounds in plants have linkages which are distinct. The effect of temperature on the release of phenolic compounds in different species therefore may not be the same (KIM et al., 2006).

The peel in natura displayed the highest levels of ascorbic acid (2,169.52 mg $\left.100 \mathrm{~g}^{-1} \mathrm{DM}\right)$, while for the other fractions, fresh or dried, the levels varied between 75.67

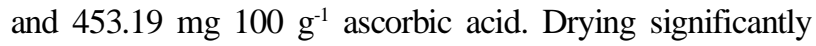
influenced these levels, with a decrease being seen in ascorbic acid levels after the process. This is because ascorbic acid is susceptible to degradation by temperature, $\mathrm{pH}$, oxygen and the enzymes which influence the degradative mechanisms, altering the concentration of the ascorbic acid, and the ratio of ascorbic acid to dehydroascorbic acid (MAEDA et al., 2007).

Although there were losses of ascorbic acid, the dried fractions presented relatively high levels (225.98 and $75.67 \mathrm{mg}$ ascorbic acid $100 \mathrm{~g}^{-1} \mathrm{DM}$, for the dried peel and seed respectively), especially for the dried peel, where the

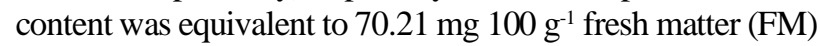
and was higher than that found for jabuticaba or pineapple (19.67 and $17.65 \mathrm{mg}$ ascorbic acid $100 \mathrm{~g}^{-1} \mathrm{FM}$ respectively) (OLIVEIRA et al., 2003; REINHARDT et al., 2004). The by-products of the lychee are therefore seen to be sources of ascorbic acid, and may be used for enriching foods, even after being dried.

The highest levels of beta-carotene were found in the lychee peel, especially in the peel in natura, which had a level which was superior to that of the other fractions (261.99 mg $\left.100 \mathrm{~mL}^{-1}\right)$. Drying significantly reduced the levels of beta-carotene in the peel, since processing is the main factor influencing degradation of the carotenoid. Thus the loss of tissue integrity, the contact with oxygen, the light and the rise in temperature during processing may all have caused degradation (PÉNICAUD et al., 2011). This behaviour was not seen in the seed however, where carotene content for these fractions, both dried and in natura, were not significantly different $(\mathrm{p}<0.05)$.
The beta-carotene is the main source of vitamin A, so even with losses due to processing, results show the nutritional potential of lychee peel as a source of beta-carotene, possibly contributing to the enrichment of diets and food products despite the bioavailability not having been studied.

The lycopene content in the seed was $0.12 \mathrm{mg}$ $100 \mathrm{~mL}^{-1}$, the carotenoid not being detected in the other fractions. With drying, there was an increase in the lycopene content of the seed, a behaviour which differs from that observed by Zanoni et al. (1999), who found a $12 \%$ loss in lycopene levels for tomatoes dried at $110{ }^{\circ} \mathrm{C}$, however no losses in levels of the nutrient were detected at $80^{\circ} \mathrm{C}$.

Antioxidant activity based on inhibition of the DPPH' radical was high for all the extracts under analysis, ranging from 12.77 to $87.18 \%$ (Table 2). Noteworthy is extract $\mathrm{D}$, prepared with $50 \%$ methanol followed by evaporation, which presented a high sequestration capacity for the DPPH• radical, displaying the greatest percentages for antioxidant activity.

Methanolic and ethanolic solutions are efficient in extracting phenolic compounds, particularly the more polar compounds such as flavonols, which indicates that the high antioxidant activity observed for this extract may be associated with the presence of these compounds or of other extractable compounds, such as anthocyanins derived from hydroxycinnamic and ellagic acids, ascorbic acid and small amounts of carotenoids, which would increase the AA. (KAJDŽANOSKA; PETRESKA; STEFOVA, 2011; MATINEZ-VALVERDE; PERIAGO; PROVAN, 2002).

The percentage of antioxidant activity observed in lychee peel for extract D, was $87.18 \%$, higher than that found by Prasad et al. (2009), who evaluated the antioxidant activity in the peel of the lychee cv. Baila subjected to extraction at high pressure and found $74 \%$ activity, and by Duan et al. (2011) who found antioxidant activity in the lychee cv. Huaizhi ranging from 60 to $25 \%$ during storage, using a methanolic solution as extractant. The differences seen between the antioxidant activity of

Table 2 - Percentages of antioxidant activity of extracts A (aqueous), B (acetone), C (1:1 solution, 70\% acetone and 50\% ethanol) and D (50\% methanol) in fractions of lychee fruit, for the DPPH' radical, Lavras, MG, 2011

\begin{tabular}{lcccc}
\hline Fraction & A & B & C & D \\
\hline Peel in natura & $25.70 \mathrm{C}$ & $63.64 \mathrm{~A}$ & $56.58 \mathrm{~A}$ & $87.18 \mathrm{~A}$ \\
Seed in natura & $47.92 \mathrm{~A}$ & $27.67 \mathrm{~B}$ & $39.12 \mathrm{C}$ & $78.42 \mathrm{~B}$ \\
Pulp in natura & $41.95 \mathrm{~B}$ & $27.25 \mathrm{~B}$ & $42.36 \mathrm{~B}$ & $31.71 \mathrm{D}$ \\
Dried peel & $16.73 \mathrm{D}$ & $19.60 \mathrm{C}$ & $21.38 \mathrm{E}$ & $40.55 \mathrm{C}$ \\
Dried seed & $15.42 \mathrm{D}$ & $12.77 \mathrm{D}$ & $32.79 \mathrm{D}$ & $18.13 \mathrm{E}$ \\
\hline
\end{tabular}

Means followed by the same letter in a column do not differ by Tukey test at $5 \%$ probability 
the fruits in this study and in that of the above authors are due to the different types of climate, maturity, cultivation and agricultural practices.

The percentage of antioxidant activity by the beta-carotene/linoleic acid system varied between 21.63 and $75.89 \%$, with the highest antioxidant activity being seen in extract B for the peel in natura, as shown in Table 3.

In all the extracts under analysis, the peel in natura showed the greatest antioxidant activity by this method, however variable results are observed when compared to those seen with $\mathrm{DPPH}^{\cdot}$ sequestration, with lower percentages for antioxidant activity, and the extracts with the greatest antioxidant activity being different for each test. Kubola and Siriamornpun (2008) evaluated the antioxidant activity of different parts of Momordica charantioa $\mathrm{L}$. and found different results for each method being analysed, demonstrating that one sample may carry out different activities in different tests.

For all the methods being analysed, there was a decrease in antioxidant activity with drying, indicating a loss of potentially antioxidant compounds. The behaviour of antioxidant activity by the $\mathrm{DPPH}^{\cdot}$ method is similar to that observed with ascorbic acid, from which it can be inferred that one of the factors responsible for the loss of antioxidant activity is the degradation of ascorbic acid due to time and exposure to oxygen during the drying process.

Principal component analysis (PCA) applied to the data explained $82.90 \%$ of the total variance in the antioxidant profile of the lychee (Figure 1). The first component (PC1) explains $60.51 \%$ of all information, and separates horizontally

Table 3 - Percentage of antioxidant activity of extracts A (aqueous), B (acetone) C (1:1 solution, 70\% acetone and 50\% ethanol) and D (50\% methanol) in fractions of lychee fruit, at a concentration of $1 \mathrm{mg} \mathrm{mL}^{-1}$, by the beta carotene/linoleic acid system, Lavras, MG, 2011

\begin{tabular}{lcccc}
\hline Fraction & A & B & C & D \\
\hline Peel in natura & $66.11 \mathrm{~A}$ & $75.89 \mathrm{~A}$ & $75.35 \mathrm{~A}$ & $75.47 \mathrm{~A}$ \\
Seed in natura & $22.66 \mathrm{D}$ & $41.44 \mathrm{C}$ & $45.82 \mathrm{~B}$ & $61.22 \mathrm{~B}$ \\
Pulp in natura & $24.94 \mathrm{C}$ & $56.44 \mathrm{~B}$ & $36.37 \mathrm{D}$ & $62.12 \mathrm{~B}$ \\
Dried peel & $21.63 \mathrm{E}$ & $28.53 \mathrm{D}$ & $28.82 \mathrm{E}$ & $29.53 \mathrm{D}$ \\
Dried seed & $36.86 \mathrm{~B}$ & $28.51 \mathrm{D}$ & $43.43 \mathrm{C}$ & $47.14 \mathrm{C}$ \\
\hline
\end{tabular}

Means followed by the same letter in a column do not differ by Tukey test at $5 \%$ probability

Figure 1 - Graphical representation of scores (I) and loads (II) from analyses of fractions of lychee fruit, evaluated in relation to the axes defined by the principal components (CP1 and CP2). In II, (b-car) corresponds to AA by the beta-carotene/linoleic acid system and (DPPH) to AA for the sequestration of the DPPH radical, for extracts of fractions of lychee fruit prepared with: (A) water, (B) acetone, (C) $70 \%$ acetone $/ 50 \%$ ethanol (v/v), (D) $50 \%$ methanol
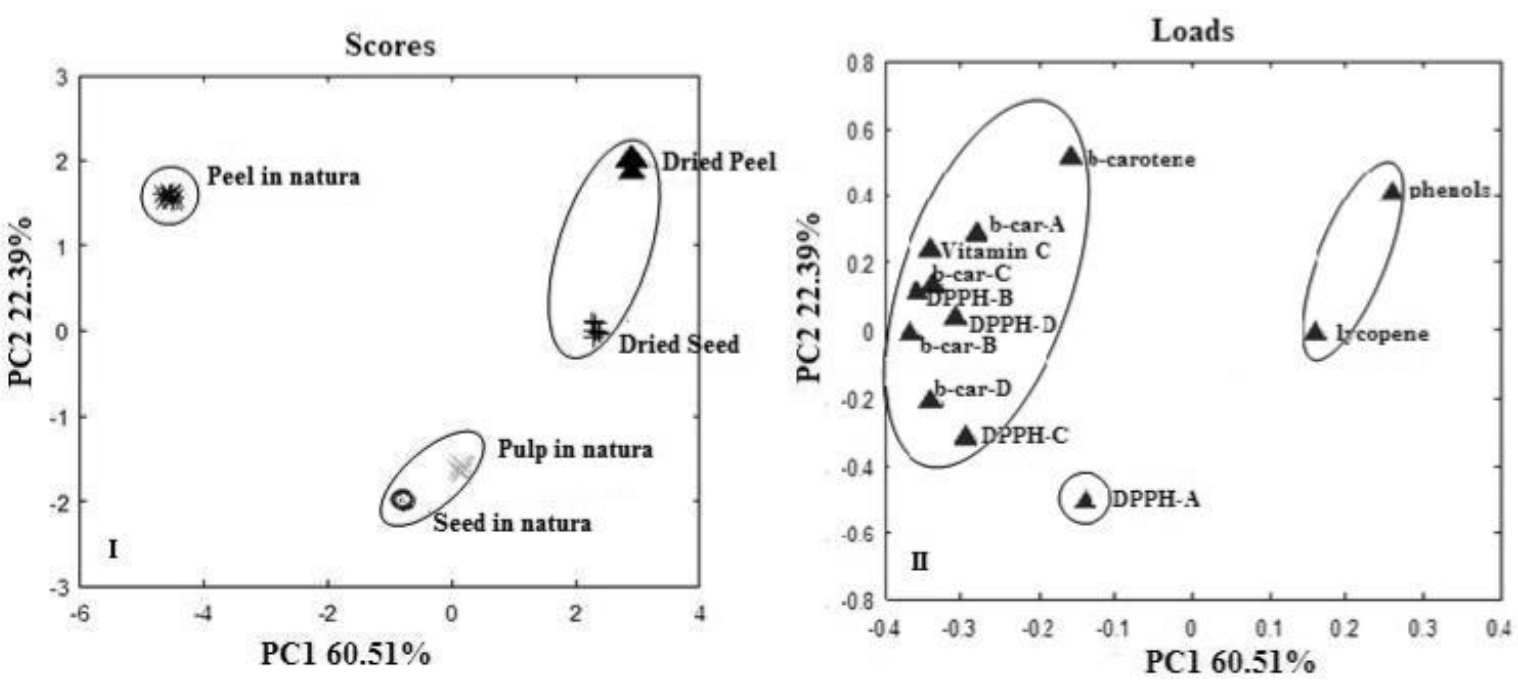
the fractions which have the highest levels of phenolic compounds (dried peel and seed) (Figure 1I). The second component (PC2) discriminates vertically the peel in natura from the other fractions, by the levels of beta-carotene, ascorbic acid and antioxidants, explaining $22.39 \%$ of the total variance. There is separation of the lychee fractions into three groups, and it can be seen that the peel in natura, which has more antioxidant activity, is distanced from the remaining fractions. Along the CP1 axis, there is separation of the dried fractions and those in natura, which reflects the type of treatment applied to the lychee fractions.

The loads characterise the trends between variables (Figure 1 II). Along the CP1 axis, it can be seen that the variables which most influenced this component are: (horizontally) phenols and lycopene, respectively the main variables for the dried peel and dried seeds, and ascorbic acid and antioxidants, the main variables for the peel in natura; and (vertically) the levels of beta-carotene (with positive values) and the antioxidant activity of extract A by the DPPH method (with negative values). It can also be seen that the antioxidant activity found in the lychee fractions in natura, is due to the ascorbic acid and betacarotene, a result that can be deduced by their proximity to the antioxidant extracts.

\section{CONCLUSIONS}

1. The lychee fractions showed high antioxidant activity, especially the peel in natura;

2. The antioxidant activity seen in the peel in natura is due to the levels of ascorbic acid and beta-carotene found in this fraction;

3. Drying at $45{ }^{\circ} \mathrm{C}$ reduces the antioxidant activity and the levels of ascorbic acid in the peel and seed of the lychee;

4. Even with the losses in antioxidant activity from drying, the peel and seed present significant antioxidant activity, which allows the use of by-products of the lychee as sources of natural antioxidants.

\section{ACKNOWLEDGEMENT}

The authors wish to thank CNPq, CAPES and FAPEMIG for their support.

\section{REFERENCES}

ASSOCIATION OF OFFICIAL ANALYTICAL CHEMISTRY. Official methods of analysis. 19. ed. Gaithersburg: Pharmabooks, 2012. 3000 p.
BHOOPAT, L. et al. Hepatoprotective effects of lychee (Litchi chinensis Sonn.): a combination of antioxidant and anti-apoptotic activities. Journal of Ethnopharmacology, v. 136, n. 1, p. 55-66, 2011.

BOARI LIMA, A. J. et al. Caracterização química do fruto jabuticaba (Myrciaria cauliflora Berg) e de suas frações. Archivos Latinoamericanos de Nutricion, v. 58, n. 4, p. 416-421 2008.

DEMBITSKY, V. M. et al. The multiple nutrition properties of some exotic fruits: biological activity and active metabolites. Food Research International, v. 44, n. 7, p. 1671-1701, 2011.

DUAN, X. et al. Effect of pure oxygen atmosphere on antioxidant enzyme and antioxidant activity of harvested litchi fruit during storage. Food Research International, v. 44, n. 7, p. 1905-1911, 2011.

DUARTE-ALMEIDA, J. M. et al. Avaliação da atividade antioxidante utilizando sistema b-caroteno/ácido linoléico e método de seqüestro de radicais DPPH. Ciência e Tecnologia de Alimentos, v. 26, n. 2, p. 446-452, 2006.

EATON, J. W. GNU Octave. Versão 3.4.3. Disponível em: <http://www.gnu.org/software/ octave/download.html>. Acesso em: 11 fev. 2013.

EBUN, O.; SANTOSH, K. Effect of domestic cooking on the polyphenolic content and antioxidant capacity of plantain (Musa paradisiaca). World Journal of Dairy \& Food Sciences, v. 6, n. 2, p. 189-194, 2011.

FALLER, A. L. K.; FIALHO, E. The antioxidant capacity and polyphenol content of organic and conventional retail vegetables after domestic cooking. Food Research International, v. 42, n. 1, p. 210-215, 2009.

FERREIRA, D. F. Sisvar: a computer statistical analysis system. Ciência e Agrotecnologia, v. 35, n. 6 p. 1039-1042, 2011.

HARBOURNE, N. et al. Effect of drying methods on the phenolic constituents of meadowsweet (Filipendula ulmaria) and willow (Salix alba). Food Science and Technology, v. 42, n. 9, p. 1468-1473, 2009.

JIANG, G. et al. Identification of a novel phenolic compound in litchi (Litchi chinensis Sonn.) pericarp and bioactivity evaluation. Food Chemistry, v. 136, n. 2, p. 563-568, 2013.

KAJDŽANOSKA, M.; PETRESKA, J.; STEFOVA, M. Comparison of different extraction solvent mixtures for characterization of phenolic compounds in strawberries. Journal of Agricultural and Food Chemistry, v. 59, n. 10, p. 5272-5278, 2011.

KIM, S. Y. et al. Effect of heating conditions of grape seeds on the antioxidant activity of grape seed extracts. Food Chemistry, v. 97 , n. 3, p. 472-479, 2006.

KUBOLA, J.; SIRIAMORNPUN, S. Phenolic contents and antioxidants activities of bitter gourd (Momordica charantia L.) leaf, stem and fruit fractions extracts in vitro. Food Chemistry, v. 110, n. 4, p. 881-890, 2008.

KUMAR, V.; KUMAR, G.; SHARMA, P. D. Osmotic dehydration of litchi pulp as a pretreatment for drying processes. Agricultural Engineering International: CIGR Journal, v. 14, n. 3, p. 146-151, 2012. 
LEE, S. C. et al. Effect of far-infrared radiation on the antioxidant activity of rice hulls. Journal of Agricultural and Food Chemistry, v. 51, n. 15, p. 4400-4403, 2003.

MAEDA, R. N. et al. Estabilidade de ácido ascórbico e antocianinas em néctar de camu-camu (Myrciaria dubia $(\mathrm{H}$. B. K.) McVaugh). Ciência e Tecnologia de Alimentos, v. 27, n. 2, p. 313-316, 2007.

MATINEZ-VALVERDE, I.; PERIAGO, M. J.; PROVAN, G. Phenolic compounds, lycopene and antioxidant activity in comercial varieties of tomato (Lyacopersicum esculentum). Journal of the Science of Food and Agriculture, v. 82, n. 3, p. 323-330, 2002.

NAGATA, M.; YAMASHITA, I. Simple method for simultaneous determination of chlorophyll and carotenoids in tomatoes fruit. Nippon Shokuhin Kogyo Gakkaish, v. 39, n. 10, p. 925-928, 1992.

OLIVEIRA, A. L. et al. Caracterização Tecnológica de Jabuticabas 'Sabará' Provenientes de Diferentes Regiões de Cultivo. Revista Brasileira de Fruticultura, v. 25, n. 3, p. 397-400, 2003.

PÉNICAUD, C. et al. Degradation of $\beta$-carotene during fruit and vegetable processing or storage: reaction mechanisms and kinetic aspects: a review. Fruits, v. 66, n. 6, p. 417-440, 2011.

PINELO, M.; ARNOUS, A.; MEYER, A. S. Upgrading of grape skins significance of plant cell-wall structural components and extraction techniques for phenol release. Trends in Food Science and Technology, v. 17, n. 11, p. 579-590, 2006.
PRASAD, N. K. et al. Effects of high-pressure treatment on the extraction yield, phenolic content and antioxidant activity of litchi (Litchi chinensis Sonn.) fruit pericarp. International Journal of Food Science and Technology, v. 44, n. 5, p. 960-966, 2009.

QUEIROZ, E. R.; ABREU, C. M. P.; OLIVEIRA, K. S. Constituintes químicos das frações de lichia in natura e submetidas à secagem: potencial nutricional dos subprodutos. Revista Brasileira de Fruticultura, v. 34, n. 4, p. 1174-1179, 2012.

REINHARDT, D. H. et al. Gradientes de qualidade em abacaxi 'Pérola' em função do tamanho e do estádio de maturação do fruto. Revista Brasileira de Fruticultura, v. 26, n. 3, p. 544-546, 2004.

SÁNCHEZ-MORENO, C. Review: methods used to evaluate the free radical scavenging activity in foods and biological systems. Food Science and Technology International, v. 8, n. 3, p. 121-137, 2002.

SMARSI, R. C. et al. Efeito da adubação nitrogenada na produção de mudas de lichieira. Revista Ceres, v. 58, n. 1, p. 129-131, 2011.

STROHECKER, R.; HENNING, H. M. Analisis de vitaminas: metodos comprobados. Madrid: Paz Montalvo, 1967. 428 p.

$\mathrm{XU}, \mathrm{X}$. et al. Flavonoid Glycosides from the seeds of Litchi chinensis. Journal of Agricultural and Food Chemistry, v. 59, n. 4, p. 1205-1209, 2011.

ZANONI, B. et al. Oxidative heat damage of tomato halves as affected by drying. Food Research International, Barking, v.31, n. 5, p. 395-401, 1999 